\title{
Purification of an inducible L-valine dehydrogenase of Streptomyces coelicolor A3(2)
}

\author{
Rosa M. Navarrete, † Jesús A. Vara† and C. Richard Hutchinson* \\ School of Pharmacy and Department of Bacteriology, University of Wisconsin, Madison, Wisconsin 53706, USA
}

(Received 31 July 1989; revised 6 October 1989; accepted 18 October 1989)

\begin{abstract}
Valine dehydrogenase (VDH) from Streptomyces coelicolor A3(2) was purified from cell-free extracts to apparent homogeneity. The enzyme had an $M_{\mathrm{r}} 41000$ in denaturing conditions and an $M_{\mathrm{r}} \mathbf{7 0 0 0 0}$ by gel filtration chromatography, indicating that it is composed of two identical subunits. It oxidized $\mathrm{L}$-valine and $\mathrm{L}$ - $\alpha$-aminobutyric acid efficiently, L-isoleucine and L-leucine less efficiently, and did not act on D-valine. It required NAD ${ }^{+}$as cofactor and could not use NADP+ ${ }^{+}$. Maximum dehydrogenase activity with valine was at $\mathrm{pH} 10.5$ and the maximum reductive amination activity with 2-oxoisovaleric acid and $\mathrm{NH}_{4} \mathrm{Cl}$ was at $\mathrm{pH} 9$. The enzyme exhibited substrate inhibition in the forward direction and a kinetic pattern with $\mathrm{NAD}^{+}$that was consistent with a sequential ordered mechanism with non-competitive inhibition by valine. The following Michaelis constants were calculated from these data: L-valine, 10.0 mM; NAD ${ }^{+}, 0.17 \mathrm{~mm}$; 2-oxoisovalerate, $0.6 \mathrm{~mm}$; and NADH, 0.093 mM. In minimal medium, $\mathrm{VDH}$ activity was repressed in the presence of glucose and $\mathrm{NH}_{4}^{+}$, or glycerol and $\mathrm{NH}_{4}^{+}$or asparagine, and was induced by $\mathrm{D}$ - and $\mathrm{L}$-valine. The time required for full induction was about $24 \mathrm{~h}$ and the level of induction was 2- to 23-fold.
\end{abstract}

\section{Introduction}

Branched-chain amino acids are normally catabolized in bacteria by dehydrogenation to a 2-oxoacid, followed by its oxidative decarboxylation to the coenzyme A derivative of a branched-chain fatty acid by a 2-oxoacid dehydrogenase complex (Massey et al., 1976; Matin et al., 1973). The latter compound can be converted to the coenzyme A esters of simpler fatty acids by the pathway shown in Fig. 1, or used as the primer for the synthesis of branched-chain fatty acids (Massey et al., 1976; Matin et al., 1973). Several L-amino acid dehydrogenases have been purified from different bacterial sources (Asano et al., 1987; Porumb et al., 1987; Schutte et al., 1985; Vancura et al., 1989; Vancurova et al., 1988b) and some of them are inducible by their normal substrates (Asano et al., 1987; Omura et al., 1984a). The L-alanine dehydrogenase from Bacillus cereus is thought to play a role in the sporulation of this organism (Porumb et al., 1987), whereas the physiological role of the other

† Present address: Centro de Investigaciones Biomédicas-CSIC, Facultad de Medicina, Universidad Autónoma, Arzobispo Morcillo 4, 28029 Madrid, Spain.

Abbreviation: VDH, valine dehydrogenase. bacterial amino acid dehydrogenases is uncertain, except for their use in fatty acid synthesis.

In Streptomyces spp., the catabolic products of amino acids can be incorporated into the carbon skeleton of some antibiotics (Dotzlaf et al., 1984; Madduri et al., 1989; Omura \& Tanaka, 1984) and esterified to macrolide antibiotics (Omura \& Tanaka, 1984), as well as being used for the synthesis of branched-chain fatty acids (Vancura et al., 1987). Valine degradation in these bacteria takes a somewhat different course (Sherman et al., 1986) than in other bacteria (Massey et al., 1976; Matin et al., 1973), particularly the unusual formation of $n$-butyrate from isobutyrate by an intramolecular rearrangement (Fig. 1) (Brendelberger et al., 1988; Reynolds et al., 1988; Sherman et al., 1986). The valine catabolites, butyrate and 2-methylmalonate, plus the acetate and propionate derived from them are incorporated into the aglycone structures of the macrolide antibiotics tylosin (Omura et al., 1984a) and leucomycin (Omura et al., 1983b), and into the polyether antibiotics monensin A (Pospisil et al., 1983; Sood et al., 1988) and lasalocid A (Sherman et al., 1986). Furthermore, in studies of Streptomyces fradiae mutants, it has been shown that the production of tylactone (the aglycone of tylosin) is positively correlated with the level of a valine dehydrogenase (Omura et al., 1983a). 

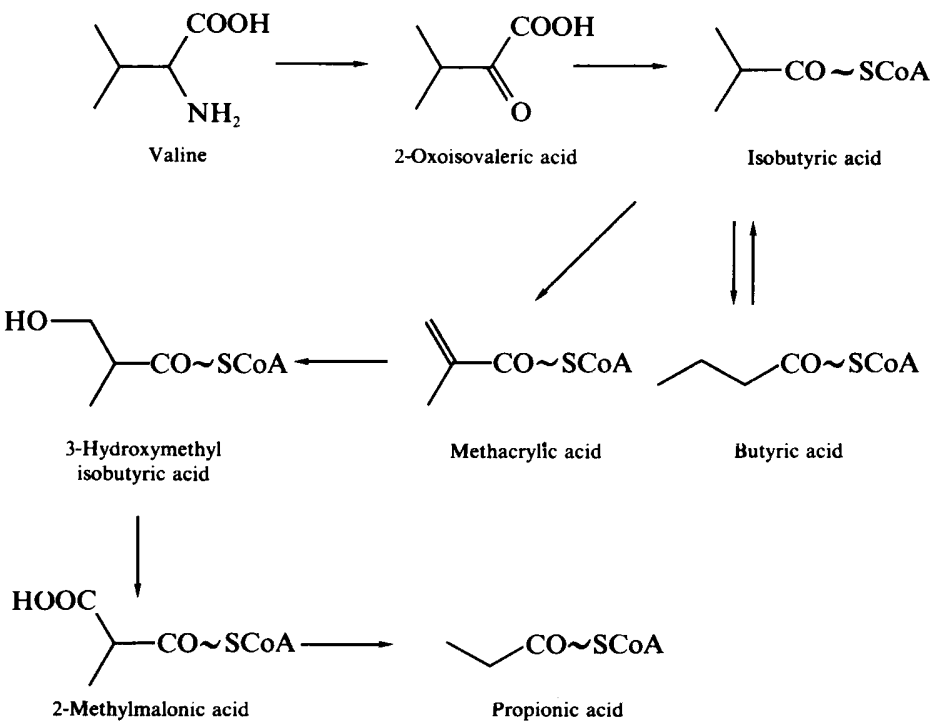

2-Oxoisovaleric acid

Isobutyric acid

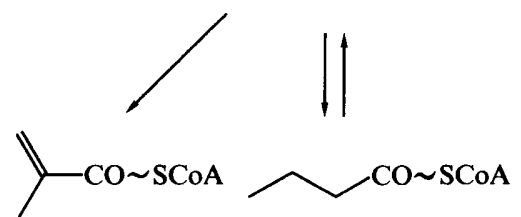

Methacrylic acid

Butyric acid

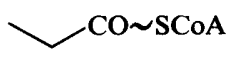

Propionic acid

Fig. 1. The catabolic pathway of L-valine in Streptomyces. The fatty acids following 2-ketoisovaleric acid are shown as their coenzyme A esters, although this has not been established experimentally.

These facts indicate a metabolic connection between valine catabolism and the biosynthesis of macrolide or polyether antibiotics in Streptomyces. Since the genetics of valine catabolism would best be studied in Streptomyces coelicolor A3(2) to capitalize on the vast amount of genetic information available about this organism (Hopwood, 1988; Hutchinson, 1988), we have purified and partially characterized an inducible L-valine dehydrogenase (VDH) from $S$. coelicolor. Many of the properties of this enzyme resemble those of the other bacterial L-amino acid dehydrogenases; however, the fact that it is a dimeric protein composed of $M_{\mathrm{r}} 40000$ subunits and that, in minimal medium, its induction by $\mathrm{L}$-valine is repressed by glucose $+\mathbf{N H}_{4}^{+}$, set it apart from the recently described VDH of Streptomyces aureofaciens (Vancurova et al., 1988a). The induction of VDH in various actinomycetes, as noted herein, and the ensuing production of simple acyl-CoA esters explains why fermentation media optimized for the production of tylosin and monensin contain large amounts of valine.

\section{Methods}

Organism and growth conditions. S. coelicolor A3(2), obtained from David Hopwood (John Innes Institute, Norwich, UK), was grown for about $48 \mathrm{~h}$ in the liquid YEME medium of Hopwood et al. (1985), which contained ( $\mathrm{g} \mathrm{l}^{-1}$ ): Difco yeast extract, 3; Difco malt extract, 3; Difco Bacto-peptone, 5; glucose, 10; sucrose, 340 ; and $2.5 \mathrm{M}$ $\mathrm{MgCl}_{2} \cdot 6 \mathrm{H}_{2} \mathrm{O}, 2 \mathrm{ml}$. The cells were collected under sterile conditions, suspended in the minimal medium (MM) of Hopwood et al. (1985) [which normally contains, ( $\mathrm{g} \mathrm{F}^{-\mathrm{T}}$ ): L-asparagine, $0.5 ; \mathrm{K}_{2} \mathrm{HPO}_{4}, 0.5$; $\mathrm{MgSO}_{4} .7 \mathrm{H}_{2} \mathrm{O}, 0.2 ; \mathrm{FeSO}_{4} .7 \mathrm{H}_{2} \mathrm{O}, 0.01$; and glucose, 10] without glucose or a nitrogen source but containing L-valine $\left(10 \mathrm{~g} \mathrm{l}^{-1}\right)$, and incubated for $24 \mathrm{~h}$ more under the same conditions. The induced cells were collected by suction filtration and stored at $-80^{\circ} \mathrm{C}$ until used, usually within less than 2 weeks.

Enzyme purification. All procedures were carried out at $4{ }^{\circ} \mathrm{C}$ except for fast protein liquid chromatography, which was done at room temperature and the fractions collected kept on ice. A cell-free extract was prepared starting with $65 \mathrm{~g}$ of frozen cells that were thawed and suspended in $200 \mathrm{ml} 50 \mathrm{~mm}$-potassium phosphate $\mathrm{pH} \mathrm{7.5,10 \% (v/v)}$ glycerol, $1 \mathrm{~mm}$-EDTA, and $5 \mathrm{~mm}-\beta$-mercaptoethanol (PGEM buffer). The suspension was sonicated in a Branson model 185 sonifier set at $40 \%$ scale intensity for six periods of 5 min each with 5 min intervals. The extract was centrifuged in a type $45 \mathrm{Ti}$ Beckman rotor at 36000 r.p.m. $(100000 \mathrm{~g})$ for $2 \mathrm{~h}$ and the supernatant was used as the source of enzyme.

The cell-free extract was passed through a Q-Sepharose (Pharmacia) column $(4 \times 5 \mathrm{~cm})$ previously equilibrated with PGEM buffer. After applying the extract, the column was washed with $100 \mathrm{ml}$ of this buffer and then with $300 \mathrm{ml}$ of buffer containing $0.05 \mathrm{M}-\mathrm{KCl}$, and both fractions were discarded. The enzyme was eluted from the column with $150 \mathrm{ml}$ of PGEM buffer containing $0 \cdot 1 \mathrm{M}-\mathrm{KCl}$. The fractions were concentrated to $40 \mathrm{ml}$ with a Spectra/Por ultrafilter type C $\left(50000 M_{\mathrm{r}}\right.$ cutoff) using dilution with buffer twice to reduce the $\mathrm{KCl}$ concentration.

The previous fraction was loaded in two portions onto an HR5/20 Mono $Q$ column (Pharmacia) previously equilibrated with the same buffer, the column was washed with the equilibrating buffer, and the following gradient was applied: buffer A was PGEM and buffer B was PGEM containing $2 \mathrm{M}-\mathrm{KCl}$. At a flow rate of $2 \mathrm{ml} \mathrm{min}^{-1}$, the column was washed with $100 \%$ buffer A for $5 \mathrm{~min}$, buffer A with 0-9\% buffer B over a period of $60 \mathrm{~min}, 100 \%$ of buffer $B$ during $30 \mathrm{~min}$, then reequilibrated with buffer $A$ for $40 \mathrm{~min}$. The active fractions appearing at $6 \%$ buffer $\mathrm{B}$, i.e. about $120 \mathrm{mM}-\mathrm{KCl}$, were pooled and dialysed against $50 \mathrm{~mm}$-Tris/ $\mathrm{HCl} \mathrm{pH} \mathrm{7 \cdot 5,10 \% (v/v)} \mathrm{glycerol,} 1 \mathrm{~mm}-\mathrm{EDT} A$, and 5 mM- $\beta$-mercaptoethanol (TGEM) buffer.

The previous fraction was loaded onto the same Mono $Q$ column previously equilibrated with TGEM buffer, the column was washed 


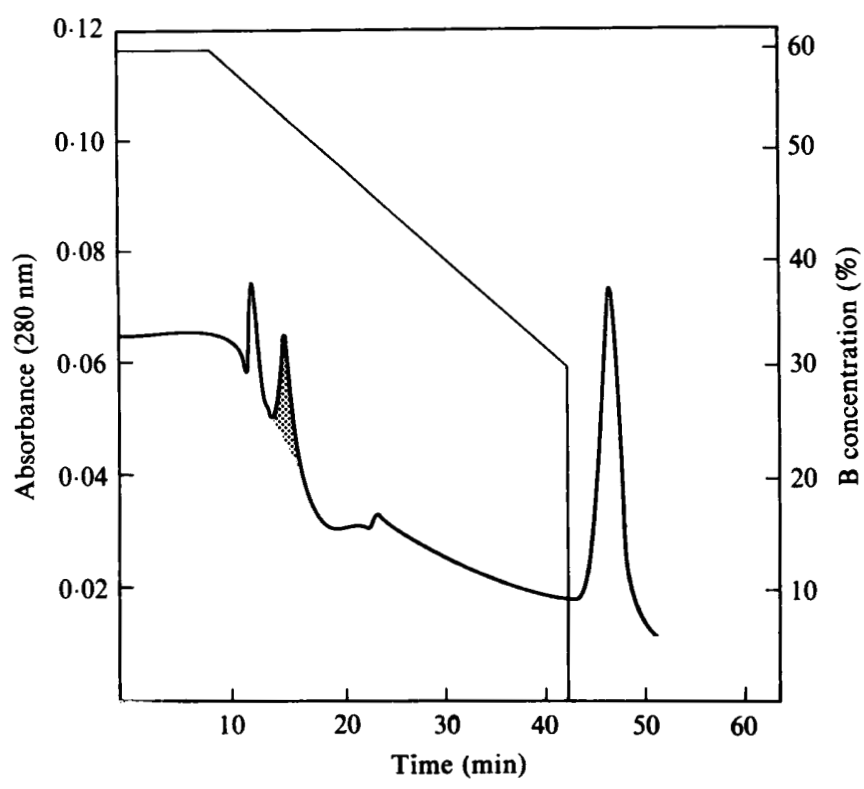

Fig. 2. Alkyl-Superose chromatography of $S$. coelicolor A3(2) VDH. The conditions are described in Methods. Buffer A is PEM and buffer $\mathrm{B}$ is PEM with $2 \mathrm{M}-\left(\mathrm{NH}_{4}\right)_{2} \mathrm{SO}_{4}$. The peak with $\mathrm{VDH}$ activity is shaded, and the decrease in the base line is due to the decreasing concentration of $\left(\mathrm{NH}_{4}\right)_{2} \mathrm{SO}_{4}$.

with the equilibrating buffer, and the following gradient was applied (buffer A was TGEM and buffer B was TGEM containing $1 \mathrm{M}-\mathrm{KCl}$ ) at a flow rate of $2 \mathrm{ml} \mathrm{min}^{-1}: 100 \%$ buffer $\mathrm{A}$ for $5 \mathrm{~min}$, buffer A with 9 $25 \%$ of buffer $B$ over a period of $60 \mathrm{~min}$, then column washing and reequilibration as above. VDH activity appeared at $18 \%$ buffer $B$, i.e. about $180 \mathrm{~mm}-\mathrm{KCl}$.

The active fraction was dialysed against $1.5 \mathrm{M}-\left(\mathrm{NH}_{4}\right)_{2} \mathrm{SO}_{4}$ in PEM buffer ( 50 mM-potassium phosphate pH 7.5, 1 mM-EDTA, $5 \mathrm{mM}-\beta$ mercaptoethanol) and loaded onto an HR5/5 Alkyl-Superose column (Pharmacia) that was developed with buffers A (PEM) and B [PEM containing $2 \mathrm{M}-\left(\mathrm{NH}_{4}\right)_{2} \mathrm{SO}_{4}$ ]. The column was equilibrated with buffer A, the sample was loaded (at $0.5 \mathrm{ml} \mathrm{min}^{-1}$ ) with $75 \%$ of buffer $B$ in buffer $A$, and the column was washed for $5 \mathrm{~min}$. The column then was washed with $60 \%$ buffer $B$ in buffer $A$ for $5 \mathrm{~min}, 60-30 \%$ buffer $B$ in buffer $A$ over $35 \mathrm{~min}$, and buffer $A$ for $25 \mathrm{~min}$. The active $3 \mathrm{ml}$ fraction (see Fig. 2) was dialysed overnight against 11 of PGEM buffer and stored at $-80^{\circ} \mathrm{C}$. Some decrease in the specific activity of the purified enzyme was observed upon long periods of storage (>one month).

Enzyme assay. VDH activity was determined in the direction of oxidative deamination by measuring the appearance of NADH at $340 \mathrm{~nm}$ with a Varian 2200 or Cary 14 spectrophotometer, the latter fitted with an Olis $4000 \mathrm{C}$ update system (On-line Instrument Systems, Madison, Wisconsin, USA). Two $1 \mathrm{ml}$ reaction mixtures were set up in cuvettes containing $0.5 \mathrm{~mm}-\mathrm{NAD}^{+}$in 50 mM-CAPS buffer, pH 9. Valine was added to one of them in concentrations varying from 2 to $80 \mathrm{~mm}$ and both cuvettes were preincubated at $30^{\circ} \mathrm{C}$ for $2 \mathrm{~min}$. The enzyme reaction was started by adding extract containing 0.5 or $1 \mu \mathrm{g}$ of purified enzyme and recorded for 1-5 min. The initial velocity was determined from plots using a molar absorption coefficient of $6.22 \times 10^{3} \mathrm{M}^{-1} \mathrm{l}^{-1}$ for NADH and full-scale absorbances of 0.05 or $0 \cdot 1$. One unit of activity is defined as the amount of enzyme required to form $1 \mu \mathrm{mol}$ of NADH in $1 \mathrm{~min}$ under the assay conditions.

The data from two determinations per sample were fitted by nonlinear least squares regression to equation 1 or 2 using the BASIC program of Duggleby (1984) on a NorthStar Horizon computer:

$$
\begin{gathered}
v=V A /\left(K+A+A^{2} / K_{\mathrm{i}}\right) \\
v=V A B /\left[K_{\mathrm{b}} \mathrm{A}\left(1+\mathrm{A} / K_{\mathrm{i}}\right)+K_{\mathrm{a}} B+A B\left(1+A / K_{\mathrm{i}}\right)+K_{\mathrm{ia}} K_{\mathrm{b}}\right]
\end{gathered}
$$

where $v$ is the measured velocity, $V$ the maximal velocity, $K_{\mathrm{a}}$ and $K_{\mathrm{b}}$ the Michaelis-Menten constants, $K_{\mathrm{i}}$ the substrate inhibition constant, $K_{\mathrm{ia}}$ the dissociation constant of $\mathrm{A}$, and $A$ and $B$ the substrate concentrations. The data obtained with varying concentrations of $\mathrm{NAD}^{+}$from 20 to $300 \mu \mathrm{M}$ and fixed concentrations of valine $(10,20,30$ and $40 \mathrm{mM})$ were analysed in the same way.

The activity was determined in the direction of reductive amination by measuring the disappearance of NADH using varying concentrations of 2-oxoisovaleric acid or NADH at fixed, saturating concentrations of the non-variant substrate in a $0.75 \mathrm{M}-\mathrm{NH}_{4} \mathrm{Cl} / \mathrm{NH}_{4} \mathrm{OH}$ buffer (pH 9) as described by Porumb et al. (1987). One unit of activity is defined as the amount of enzyme required to consume $1 \mu \mathrm{mol}$ of NADH in $1 \mathrm{~min}$ under the assay conditions.

Chemicals, reagents and general methods. NAD ${ }^{+}, \mathrm{NADH}$, all amino acids and specialized reagents were purchased from Sigma. All other chemicals were of reagent grade. Protein concentration was determined by the method of Bradford (1976). Cell densities were measured with a Bausch and Lomb Spectronic 20 spectrophotometer using fresh growth medium as the blank.

\section{Results}

\section{Purification of VDH from S. coelicolor}

VDH activity in cell extracts was initially found to be rather unstable and could not be preserved at low temperature. A preliminary study with crude extracts from induced cells established that the use of glycerol $(10 \%)$ and to a lesser extent polyethylene glycol MW $1000(10 \%$, w/v) preserved VDH activity. The enzyme activity was equally stable in $50 \mathrm{~mm}$-Tris or phosphate buffers at $\mathrm{pH} 7 \cdot 5$, and was more stable in the presence of $5 \mathrm{mM}$ - $\beta$-mercaptoethanol than $0.5 \mathrm{mM}$-dithiothreitol. Addition of $1 \mathrm{mM}$-EDTA also helped preserve the activity. Neither valine nor $p$-methylphenylsulphonyl fluoride helped to preserve the activity, and the possible stabilizing effect of $\mathrm{NAD}^{+}$or $\mathrm{NADH}$ was not determined.

We developed a rapid rather than a high-yield purification process, aimed at providing sufficient enzyme for partial characterization and amino acid sequence analysis. This was carried out as described in Methods, and the results of a typical purification are shown in Table 1. Our procedure resulted in homogeneously pure VDH with a 143-fold purification and a $4 \%$ recovery of the activity in the crude extract. The silverstained gel also shows (Fig. 3, lane 3 versus 4 ) the considerable improvement in the enzyme purification resulting from the two different buffers used for the Mono Q chromatography steps. Nearly pure enzyme was obtained with a $43 \%$ recovery of initial activity after the 
Table 1. Purification of VDH from S. coelicolor A3(2)

\begin{tabular}{lccccc}
\hline \hline Fraction & $\begin{array}{c}\text { Protein } \\
(\mathbf{m g})\end{array}$ & $\begin{array}{c}\text { Activity } \\
(\mathrm{U})\end{array}$ & $\begin{array}{c}\text { Specific activity } \\
{[\mathbf{U}(\mathbf{m g} \text { protein) }}\end{array}$ & $\begin{array}{c}\text { Purification } \\
(- \text { fold })\end{array}$ & $\begin{array}{c}\text { Yield } \\
(\%)\end{array}$ \\
\hline Crude & 550 & 75 & 0.14 & 1 & $(100)$ \\
Q-Sepharose & 34 & 67 & 1.7 & 13 & 89 \\
Mono Q (PO $)$ & 13 & 34 & 2.6 & 19 & 46 \\
Mono Q (Tris) & 1.6 & 25 & 15 & 115 & 43 \\
Alkyl-Superose & $\mathbf{0 . 2}$ & 3.3 & 19 & 143 & 4 \\
\hline \hline
\end{tabular}

second Mono Q chromatography (Fig. 3, lane 4), but more than $90 \%$ of this activity was lost in the subsequent Alkyl-Superose chromatography step. This was due to the fact that, prior to this last step, the enzyme fraction had to be dialysed to remove glycerol and the $\left(\mathrm{NH}_{4}\right)_{2} \mathrm{SO}_{4}$ concentration adjusted to $1.5 \mathrm{M}$ to promote the hydrophobic binding of the protein to the Alkyl-Superose column. The glycerol had to be removed because it has the opposite effect to $\left(\mathrm{NH}_{4}\right)_{2} \mathrm{SO}_{4}$ on protein binding, even though the enzyme was highly unstable in the absence of glycerol. Moreover, $\left(\mathrm{NH}_{4}\right)_{2} \mathrm{SO}_{4}$ caused a high amount of enzyme inactivation. Hydrophobic interaction chromatography was the only way tested to further purify the enzyme, since we were not successful in several attempts to purify it by affinity chromatography using Reactiveblue 2 Sepharose, -blue 4 Agarose, -brown 10 Agarose, -red 120 Agarose, or -yellow 86 Agarose, NAD-agarose, or valine-Agarose (Sigma). After the Alkyl-Superose step, the VDH activity was associated with a single protein band in SDS-PAGE (Fig. 3, lane 5). The highest specific activity found was $17-23 \mathrm{U}$ (mg protein) ${ }^{-1}$ when assayed as described in Methods (but at pH 10.5 rather than 9).

Under denaturing conditions (Fig. 3) the $M_{\mathrm{r}}$ of the protein was estimated to be $40000-42000$. In an $8-25 \%$ gradient denaturing Phastgel (Pharmacia), the protein ran with an apparent $M_{\mathrm{r}}$ of 38000 . The $M_{\mathrm{r}}$ of the native protein was determined by gel filtration through Superose $6 \mathrm{HR} 1 / 30$ (Pharmacia) using the PGEM buffer containing $100 \mathrm{mM}-\mathrm{KCl}$ and bovine serum albumin $\left(M_{\mathrm{r}}\right.$ $66200)$, ovalbumin $\left(M_{\mathrm{r}} 45000\right)$, carbonic anhydrase $\left(M_{\mathrm{r}}\right.$ $31000)$ and lysozyme $\left(M_{\mathrm{r}} 14400\right)$ as standards. Under these conditions the purified protein ran as a single peak slightly ahead of bovine serum albumin; its $M_{\mathrm{r}}$ was calculated to be approximately 70000 , suggesting that the VDH is composed of two identical subunits.

\section{Substrate range and kinetic mechanism of $S$. coelicolor $V D H$}

This enzyme oxidized L-valine using $\mathrm{NAD}^{+}$as cofactor to produce 2-oxoisovaleric acid and presumably $\mathrm{NH}_{4}^{+}$; no activity was observed using NADP+. The $\mathrm{pH}$ for maximum activity was 10.5 (no higher $\mathrm{pH}$ was assayed); at $\mathrm{pH} 10.0$ the activity was $15 \%$ lower. As shown in Table 2, $\mathrm{L}$ - $\alpha$-aminobutyric acid was a better substrate for the enzyme than L-valine, and four other L-amino acids were poorer substrates in the following order of decreasing reactivity: isoleucine, leucine, alanine and cysteine. D-Valine was not a substrate for the enzyme, and neither were the six other L-amino acids tested.

- The enzyme was assayed in the reverse direction using 2-oxoisovaleric acid plus $\mathrm{NH}_{4}^{+}$and NADH. NADPH could not replace $\mathrm{NADH}$, and the $\mathrm{pH}$ for maximum activity was 9 , with a $10 \%$ lower activity at $\mathrm{pH} 9.5$ and a $40 \%$ lower activity at $\mathrm{pH} 8.5$.

The kinetic constants for valine, 2-oxoisovaleric acid and $\mathrm{NAD}(\mathrm{H})$ were determined at $\mathrm{pH} 9$ (rather than pH 10.5 where the initial velocities were too imprecise) with 0.5 and $1.0 \mu \mathrm{g}$ of purified enzyme as described in Methods. At valine concentrations higher than $\sim 20 \mathrm{mM}$ the enzyme exhibited substrate inactivation (Fig. 4a). The $1 / v$ versus $1 /\left[\mathrm{NAD}^{+}\right]$plots, at four different valine concentrations, gave a set of lines intersecting to the left of the $y$-axis (Fig. $4 b$ ) whose pattern of first decreasing then increasing slopes and $y$-intercepts with increasing valine concentration is consistent with a sequential ordered mechanism with non-competitive inhibition by valine (Cleland, 1979). Normally, the kinetic constants can be extracted from patterns such as that in Fig. 4(b), but attempts to fit the data to a rate equation for a sequential, ordered, bisubstrate reaction with noncompetitive inhibition by one substrate (equation 2 , see Methods) (Cleland, 1979) did not yield convergence. Therefore, we fitted the data for valine to a simpler rate equation for substrate inhibition (equation 1, see Methods) (Cleland, 1979). The $K_{\mathrm{m}}$ for valine thus calculated was $10.0 \pm 1.6 \mathrm{mM}$, the $K_{\mathrm{i}} 36.8 \pm 5.8 \mathrm{mM}$, and the $V 6.92 \pm 0.7 \mathrm{U} \mathrm{mg}^{-1}$. Using the data for $20 \mathrm{~mm}$ valine, the corresponding values for $\mathrm{NAD}^{+}$were $K_{\mathrm{m}}$ $0.17 \pm 0.02 \mathrm{mM}$ and $V 6.25 \pm 0.8 \mathrm{U} \mathrm{mg}^{-1}$. For 2-oxoisovaleric acid, in assays run at $\mathrm{pH} 9$ with an NADH concentration of $2 \mathrm{mM}$, an $\mathrm{NH}_{4}^{+}$concentration of $750 \mathrm{~mm}$, and 2-oxoacid concentrations from 0.25 to $5 \mathrm{mM}$, the $K_{\mathrm{m}}$ was calculated to be $0.6 \pm 0.07 \mathrm{~mm}$ and the $V 72 \cdot 4 \pm 5 \cdot 7 \mathrm{U} \mathrm{mg}^{-1}$. Similarly, for $\mathrm{NADH}$, at a 2- 


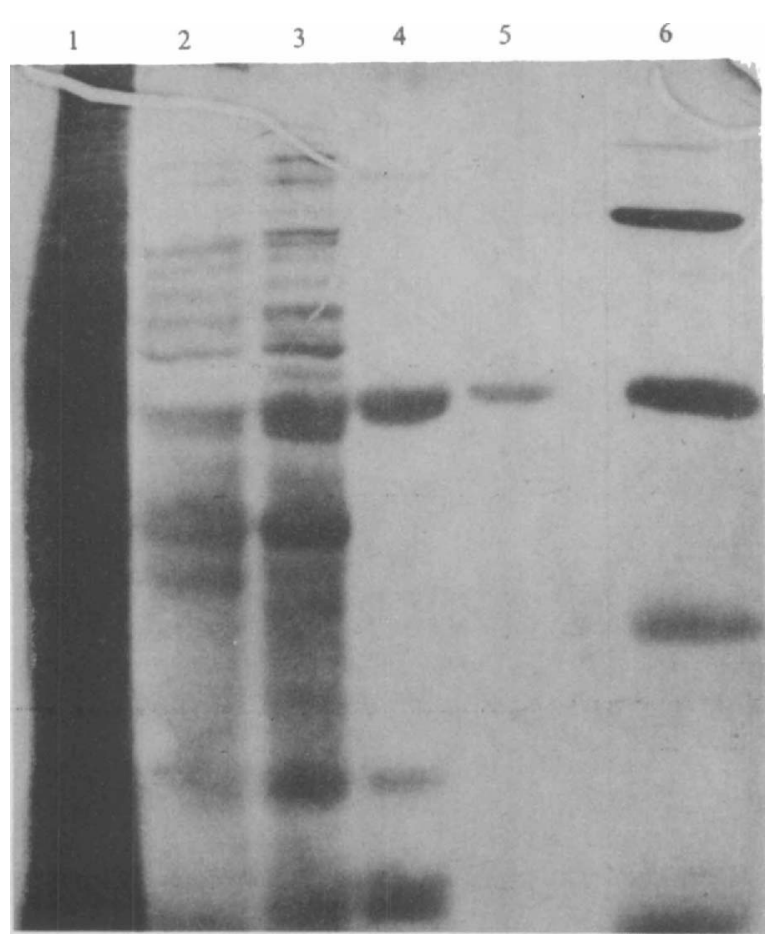

Fig. 3. Silver-stained SDS-PAGE electropherogram of the fractions listed in Table 1. Lanes: 1 , crude extract $(10 \mu \mathrm{g}) ; 2, \mathrm{Q}$-Sepharose $(6 \mu \mathrm{g})$; 3, Mono Q-phosphate $(6 \mu \mathrm{g}) ; 4$, Mono Q-Tris $(4 \mu \mathrm{g})$; 5, Alkyl-Superose $(2 \mu \mathrm{g}) ; 6, M_{\mathrm{r}}$ standards: BSA (66200), ovalbumin (42000), carbonic anhydrase (30000), and lysozyme.(14400). The acrylamide concentration was $10 \%$ and the proteins were stained with the kit from Bio-Rad.

Table 2. Activity of the VDH from S. coelicolor A3(2) with different substrates

The enzyme activity was determined at $\mathrm{pH} 10.5$ with purified VDH, the amino acid $(20 \mathrm{mM})$, and $\mathrm{NAD}^{+}(0.5 \mathrm{mM})$ as described in Methods. The activities found with $D$-valine, $L$-asparagine, $L$ glutamine, L-phenylalanine, L-serine, L-threonine and L-tyrosine were all lower than the limit of detection of the assay $\left(0.7 \mathrm{mU}^{\mathrm{mg}}{ }^{-1}\right)$.

\begin{tabular}{lcc}
\hline \hline Substrate & $\begin{array}{c}\text { Specific activity } \\
{[\mathbf{U} \text { (mg protein) }}\end{array}$ & $\begin{array}{c}\text { Relative activity } \\
(\%)\end{array}$ \\
\hline L- $\alpha$-Aminobutyric acid & 19 & 130 \\
L-Valine & 14 & 100 \\
L-Isoleucine & $3 \cdot 8$ & 28 \\
L-Leucine & $1 \cdot 2$ & 8 \\
L-Alanine & $0 \cdot 70$ & 5 \\
L-Cysteine & 0.42 & 3 \\
\hline \hline
\end{tabular}

oxoisovaleric acid concentration of $10 \mathrm{mM}$, an $\mathrm{NH}_{4}^{+}$ concentration of $750 \mathrm{mM}$, and nucleotide concentrations from 50 to $300 \mu \mathrm{M}$, the values were $K_{\mathrm{m}} 0.093 \pm 6.5 \mathrm{mM}$ and $V 68 \cdot 8 \pm 5 \cdot 0 \mathrm{U} \mathrm{mg}^{-1}$.

\section{VDH activity in other micro-organisms}

VDH activity, measured in cells grown in Luria broth (Hopwood et al., 1985), YEME or the medium normally used for antibiotic production, was found in cell-free extracts of Bacillus subtilis, Pseudomonas fluorescens and Saccharomyces cerevisiae, but not in extracts of Escherichia coli (data not shown). Two of the actinomycetes tested, Streptomyces peucetius and Saccharopolyspora erythraea, exhibited very low VDH activity under the growth conditions tested (Table 3). S. coelicolor A3(2), Streptomyces glaucescens and Streptomyces lividans had about the same activity when grown in the YEME medium, whereas Streptomyces cinnamonensis and $S$. fradiae had no detectable activity. On the other hand, the VDH activity in $S$. cinnamonensis and $S$. fradiae was 129 -fold and 43-fold greater, respectively, in optimized monensin or tylosin production media, which contain $0 \cdot 1-0.6 \%$ valine.

\section{Induction of VDH in S. coelicolor}

The specific activity of VDH measured in cell-free extracts of $S$. coelicolor A3(2) grown in the YEME medium varied from $22 \mathrm{mU}$ (mg protein $)^{-1}$ in the early exponential phase to $36 \mathrm{mU}$ (mg protein $)^{-1}$ in the early stationary phase, then decreased to $26 \mathrm{mU}$ (mg protein $)^{-1}$ at $77 \mathrm{~h}$ and $13 \mathrm{mU}$ (mg protein) $)^{-1}$ at $96 \mathrm{~h}$ (late stationary phase). Thus, in YEME medium, which contains about $260 \mathrm{mg}$ valine $1^{-1}$ (Difco Laboratories Technical Bulletin), VDH activity was maximal in the early stationary phase of growth.

A time-course analysis of VDH activity in $\mathrm{MM}+\mathrm{L}-$ valine or $\mathrm{MM}+$ glucose and $\left(\mathrm{NH}_{4}\right)_{2} \mathrm{SO}_{4}$ showed that the enzyme activity appeared within $4 \mathrm{~h}$ after transfer of washed mycelium to fresh growth medium. VDH activity almost disappeared by $6 \mathrm{~h}$ after transfer to MM with glucose $+\left(\mathrm{NH}_{4}\right)_{2} \mathrm{SO}_{4}$, whereas it increased approximately linearly up to $24 \mathrm{~h}$ in medium containing L-valine as the only carbon (C) and nitrogen (N) source. These results (not shown) suggested that the induction of this enzyme by L-valine is repressed in the presence of a more easily available $\mathrm{C}$ (glucose) or $\mathrm{N}\left[\left(\mathrm{NH}_{4}\right)_{2} \mathrm{SO}_{4}\right]$ source.

The inducibility of VDH was then measured under different conditions of growth to assess how its activity was affected by alternative $\mathrm{C}$ and $\mathrm{N}$ sources, particularly the ones that have been used in standard $S$. coelicolor A3(2) growth media (Hopwood et al., 1985) or in studies of $\mathrm{C}$ and $\mathrm{N}$ assimilation in this organism (Fisher, 1988; Hodgson, 1982). Representative data from these experiments are listed in Table 4. In the YEME medium, the specific activity of VDH varied less than twofold in the presence or absence of valine or glucose. The amount of valine in YEME ( $\geq 2 \mathrm{~mm}$ ) must be sufficient to induce 

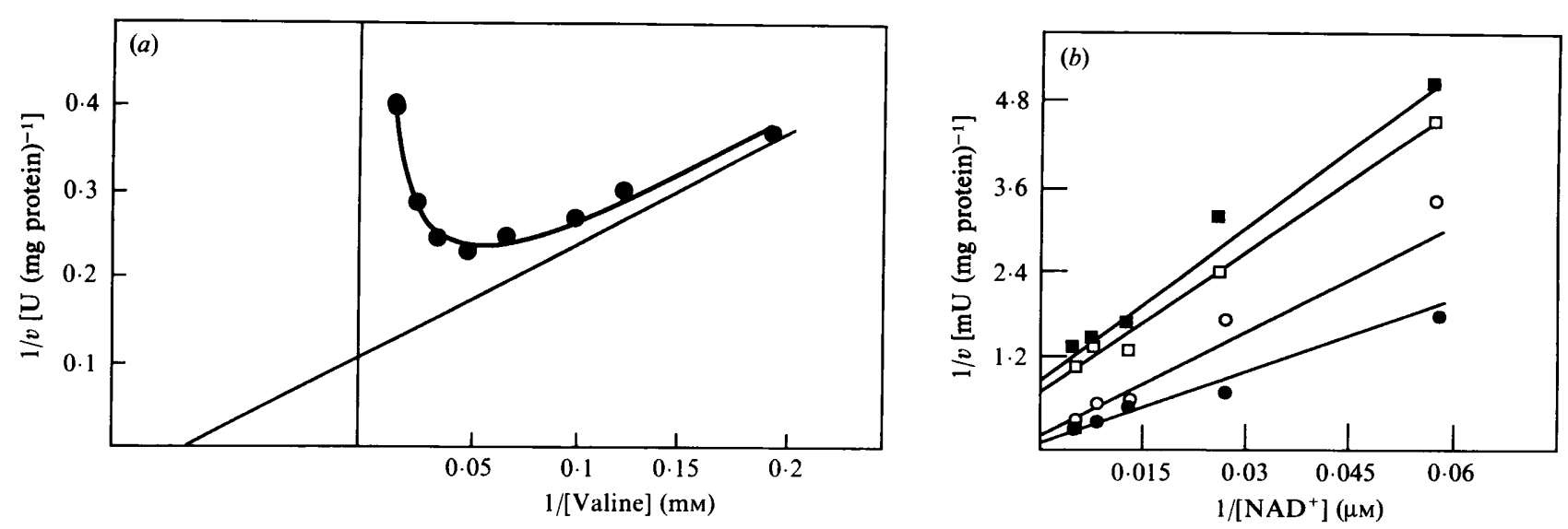

Fig. 4. (a) Double reciprocal plot of valine concentration versus $S$. coelicolor A3(2) VDH activity. The straight line was obtained by fitting the data to equation 1 (Methods) using valine concentrations from 2 to $80 \mathrm{mM}$ and $0.5 \mathrm{mM}-\mathrm{NAD}^{+}$. (b) Double reciprocal plot of $\mathrm{NAD}^{+}$concentration versus $S$. coelicolor A3(2) VDH activity. The data obtained at $10(O), 20(O), 30(\square)$ and $40(\square) \mathrm{mM}$ valine concentrations were analysed as described in Methods.

Table 3. VDH activity in different actinomycetes

\begin{tabular}{ll}
\hline \hline \multicolumn{1}{c}{ Strain } & $\begin{array}{c}\text { Specific activity* } \\
\left(\mathrm{mU} \mathrm{mg}^{-1}\right)\end{array}$ \\
\hline S. coelicolor A3(2) & 22 \\
(Culture supernatant & $<0.7)$ \\
S. glaucescens GLA.O & 26 \\
S. lividans 1326 & 24 \\
S. cinnamonensis WMH585 & $<0.7(129 \dagger)$ \\
S. fradiae GS14 & $<0.7(43 \ddagger)$ \\
S. peucetius AD2-40 & $<0.7(<0.7 \S)$ \\
Sac. erythraea WMH22 & $<0.7 \|$ \\
\hline \hline
\end{tabular}

* The enzyme activity was determined at pH 10.5 with crude cellfree supernatant prepared from cells grown in YEME or the medium specified, L-valine $(20 \mathrm{mM})$ and $\mathrm{NAD}^{+}(0.5 \mathrm{mM})$ as described in Methods.

† Grown in $\left(\mathrm{g} \mathrm{I}^{-1}\right)$ : glucose, 16.7; L-tyrosine, 3.3; DL-valine, 6.6; Llysine, $1.0 ; \mathrm{CaCO}_{3}, 1 ; \mathrm{FeSO}_{4} .7 \mathrm{H}_{2} \mathrm{O}, 0.17 ; \mathrm{K}_{2} \mathrm{HPO}_{4}, 0.05 ; \mathrm{MgSO}_{4}$, 0.67 ; biotin, 0.025 ; and folic acid, 0.025 .

‡ Grown in $\left(\mathrm{g} \mathrm{l}^{-1}\right)$ : trypticase soy broth, 20 ; L-valine, $1 ; \mathrm{CoCl}_{2}, 1$; and soybean oil, 30 .

$\S$ Grown in $\left(\mathrm{g}^{-1}\right)$ : glucose, 60 ; brewers yeast, $25 ; \mathrm{NaCl}, 2$; $\mathrm{KH}_{2} \mathrm{PO}_{4}, 1 ; \mathrm{CaCO}_{3}, 2 ; \mathrm{MgSO}_{4}, 0.1 ; \mathrm{FeSO}_{4} .7 \mathrm{H}_{2} \mathrm{O}, 0.01$; and $\mathrm{ZnSO}_{4} \cdot 7 \mathrm{H}_{2} \mathrm{O}, 0.01$.

$\|$ Grown in $\left(\mathrm{g} \mathrm{l}^{-1}\right)$ : glucose, 5; brown sugar, 10; tryptone, 5; yeast extract, $2 \cdot 5$; EDTA, 0.036; betaine, 1.29; and sodium propionate, $0 \cdot 11$.

VDH activity under these growth conditions. In MM with glucose $+\mathrm{NH}_{4}^{+}$, glycerol $+\mathrm{NH}_{4}^{+}$or glycerol + asparagine as the respective $\mathrm{C}$ and $\mathrm{N}$ sources, the level of VDH activity was below the limit of detection of the assay. Mycelium grown in MM with glucose $+\mathrm{L}-$ histidine showed about the same VDH activity as that grown in YEME. VDH activity was induced 13-fold (relative to the value for MM with glucose + histidine)
Table 4. Induction of VDH activity in S. coelicolor A3(2) in different growth media

YEME broth ( $500 \mathrm{ml}$ in a 21 flask) was inoculated with a dense $S$. coelicolor A3(2) spore suspension and the culture was incubated at 300 r.p.m. at $30^{\circ} \mathrm{C}$. The entire culture was collected at $48 \mathrm{~h}$, a portion of the cells was removed and assayed for VDH activity, while the remaining cells were washed with MM. A portion of this mycelium was resuspended in $\mathrm{MM}$ containing the specified ingredient $+\mathrm{L}$-isoleucine $\left(0.05 \mathrm{~g} \mathrm{l}^{-1}\right)$ unless stated otherwise. The concentrations of the different $\mathrm{C}$ and $\mathrm{N}$ sources were, $\mathrm{g} \mathrm{l}^{-1}$ : glucose, 10; glycerol, 10; L-valine, 10; D-valine, 10; DL-valine, 10; $\left(\mathrm{NH}_{4}\right)_{2} \mathrm{SO}_{4}, 2$; L-asparagine, 5; and L-histidine, 5. The culture was then grown at $30^{\circ} \mathrm{C}$ and 300 r.p.m. for $24 \mathrm{~h}$. No significant difference was observed in the amount of cells obtained.

\begin{tabular}{|c|c|c|}
\hline Medium & $\begin{array}{c}\text { Activity* }^{*} \\
{\left[\mathrm{mU}(\mathrm{mg} \text { protein })^{-1}\right]}\end{array}$ & $\begin{array}{l}\text { Induction } \\
\text { (fold) }\end{array}$ \\
\hline YEME & $16 \cdot 3$ & ND \\
\hline YEME + valine & 25.9 & ND \\
\hline YEME + DL-valine & $24 \cdot 4$ & ND \\
\hline YEME - glucose + valine & $22 \cdot 4$ & ND \\
\hline YEME - glucose + DL-valine & $25 \cdot 4$ & ND \\
\hline $\mathbf{M M}+$ glucose $+\mathbf{N H}_{4}^{+}$ & $<0.7 \dagger$ & - \\
\hline $\mathbf{M M}+$ glycerol $+\mathbf{N H}_{4}^{+}$ & $<0.7$ & - \\
\hline MM + glycerol + asparagine & $<0.7$ & - \\
\hline MM + glucose + histidine & $13 \cdot 6$ & 1 \\
\hline $\mathbf{M M}+$ glucose + valine & 25.9 & 1.9 \\
\hline MM + glycerol + valine & $90 \cdot 5$ & $6 \cdot 6$ \\
\hline MM + valine & 182 & 13 \\
\hline MM + valine - isoleucine & 177 & 13 \\
\hline MM + D-valine & 296 & 23 \\
\hline MM + DL-valine & 193 & 14 \\
\hline
\end{tabular}

ND, Not determined. -, Complete repression of VDH activity.

* Equal amounts of cells as determined by packed cell volume were used for each assay and the enzyme assays were done twice for each sample as described in Methods, except at $\mathbf{p H} 10.5$ instead of $\mathbf{p H} 9$.

$\dagger$ The activity was lower than the limit of detection of the assay $\left(0.7 \mathrm{mU} \mathrm{mg}^{-1}\right)$. 
when L-valine was used as the sole $\mathrm{C}$ and $\mathrm{N}$ source in MM, 23-fold by D-valine and 14-fold by DL-valine. Smaller increases in VDH activity were seen in MM with glucose + valine or glycerol + valine.

Although these data do not show the possible effect(s) of cellular metabolites on enzyme activity, the trends in VDH activity clearly show that this enzyme is strongly induced by $\mathrm{D}-, \mathrm{L}-$ or DL-valine when they are used as the sole $\mathrm{C}$ and $\mathrm{N}$ source. When valine is the sole $\mathrm{N}$ source, this strong induction of VDH is partially repressed by a more easily available $\mathrm{C}$ source (glucose or glycerol). Among the alternative $\mathrm{N}$ sources tested, $\mathrm{NH}_{4}^{+}$had the most repressive effect on the induction of VDH.

\section{Discussion}

We chose the VDH from $S$. coelicolor A3(2) for study because a subsequent investigation of the genetics of valine catabolism would lead to data comparable with the properties of the other catabolic enzymes and their genes that have been studied in this genetically wellcharacterized organism (reviewed in Hutchinson, 1988). Since VDH is the first enzyme of the valine catabolic pathway (Fig. 1), the regulation of its level and activity could be the predominant factor in regulating valine catabolism. Knowledge about this will be important later to examine the relationship between valine catabolism and antibiotic production in commercially important Streptomyces species.

Pseudomonas species degrade L-valine by transamination as well as by dehydrogenation (Massey et al., 1976; Matin et al., 1973), but we could not detect any transamination activity with L-valine and 2-oxoglutaric acid in cell-free extracts of $S$. coelicolor A3(2). Thus, this organism appears to metabolize $\mathrm{L}$-valine and possibly the other common branched-chain amino acids by an initial dehydrogenation step as has been reported for the majority of bacteria (Asano et al., 1987; Porumb et al., 1987; Schutte et al., 1985; Vancura et al., 1989; Vancurova et al., 1988b).

The $S$. coelicolor A3(2) VDH was expediently purified by exploiting the different behaviour of the protein on anion-exchange chromatography under two different (Tris/ $\mathrm{HCl}$ or potassium phosphate) buffer conditions, a method we have used previously for an enzyme from Sac. erythraea (Vara \& Hutchinson, 1988). Our purification scheme did not result in a high recovery of active VDH, however, due to the instability of the enzyme under the conditions used for hydrophobic interaction chromatography, and to the fact that we were not successful in our attempts to purify it by affinity chromatography. Priestly \& Robinson (1989) have reported that the VDH of $S$. cinnamonensis has a similar instability and insignificant binding to such affinity chromatography media.

Four L-valine dehydrogenases have now been purified from streptomycetes. The $S$. coelicolor A3(2) and $S$. cinnamonensis enzymes are dimeric and consist of two, apparently identical subunits with similar $M_{\mathrm{r}}$, while the $S$. aureofaciens enzyme is a tetramer, and the $S$. fradiae enzyme an oligomer composed of smaller-sized subunits. Three of the enzymes have similar $K_{\mathrm{m}}$ values for valine, whereas the $S$. coelicolor A3(2) VDH, which exhibited substrate inhibition in vitro (Fig. 4a), has an approximately five-fold higher value. All four enzymes have similar $K_{\mathrm{m}}$ values for 2-oxoisovaleric acid and $\mathrm{NAD}(\mathrm{H}), \mathrm{pH}$ optima in the oxidative and reductive directions [the two $\mathrm{pH}$ maxima may reflect the differing state of protonation of the coenzyme and reaction intermediates in the forward and reverse directions, as shown for L-glutamate dehydrogenase from different sources (Smith et al., 1975)], and abilities to oxidize valine, leucine, isoleucine and $\alpha$-aminobutyrate, although at different relative rates (Priestly \& Robinson, 1989; Vancura et al., 1988; Vancurova et al., 1988a).

A detailed kinetic analysis of the $S$. cinnamonensis enzyme by Priestly \& Robinson (1989) showed that the reductive amination of 2-oxoisovalerate proceeds through a sequential ordered ternary-binary mechanism. NADH binds to the enzyme first, followed by 2oxoisovalerate and then ammonia, and $L$-valine is released first followed by $\mathrm{NAD}^{+}$. An apparent $K_{\mathrm{i}}$ of $158 \pm 8 \mathrm{mM}$ was estimated for $\mathrm{NH}_{4}^{+}$in the oxidative deamination reaction (Priestly \& Robinson, 1989). Because of this high value, we believe that the VDH activity seen in the presence of valine for the four streptomycetes is not due to a significant alteration of its activity by $\mathrm{NH}_{4}^{+}$. For $S$. coelicolor A3(2), valine may have some effect on the VDH activity in vivo since it inhibits the activity in vitro at concentrations $>20 \mathrm{mM}$.

Most of the L-amino acid dehydrogenases of other bacterial genera (Asano et al., 1987; Porumb et al., 1987; Schutte et al., 1985) have larger native $M_{\mathrm{r}}$ values (255000-310000) and are composed of 6-8 subunits each. Their properties are otherwise similar to the VDHs of the Streptomyces spp. studied, which indicates that the latter enzymes should also be classified as branchedchain L-amino acid dehydrogenases.

VDH activity in $S$. coelicolor A3(2) was found only intracellularly and at all periods of growth in the rich (YEME) medium. Under these conditions, maximum enzyme activity was reached at the early stationary stage, the time of antibiotic production in this and many other streptomycetes. The level of VDH activity in MM with glucose + histidine was similar to that in the YEME medium (Table 4). It was induced from 2- to 23-fold in MM with valine as the sole $\mathrm{C}$ and $\mathrm{N}$, or $\mathrm{N}$ source, but 
was repressed by glucose $+\mathrm{NH}_{4}^{+}$, glycerol $+\mathrm{NH}_{4}^{+}$or glycerol + asparagine (Table 4). These results show that the enzyme activity is highly inducible by the normal substrate as well as by its non-metabolizable enantiomer, but strongly repressed by more readily utilizable $\mathrm{C}$ and $\mathrm{N}$ sources. The high inducibility of this enzyme in some other streptomycetes (Table 3) explains why valine is so efficiently incorporated, via its catabolism to butyrate, 2methylmalonate and propionate, into macrolide and polyether antibiotics (Dotzlaf et al., 1984; Omura et al., 1983b; Pospisil et al., 1983; Reynolds et al., 1988; Sherman et al., 1986). It may be that the acyl-CoA esters used for antibiotic biosynthesis can be provided more efficiently by valine catabolism than by the direct esterification of acetate, butyrate and propionate added to the fermentation medium.

The data in Table 4 suggest that the catabolism of valine in $S$. coelicolor A3(2) might be controlled in the same way as histidine and proline utilization in enteric bacteria (Magasanik \& Neidhardt, 1987). Since glucose or glycerol in the presence of $\mathrm{NH}_{4}^{+}$repress $\mathrm{VDH}$ activity while valine induces it, formation of this enzyme could be controlled by global carbon and nitrogen utilization regulons. On the other hand, valine catabolism differs considerably from histidine catabolism in $S$. coelicolor (Kendrick \& Wheelis, 1982) and S. griseus (Kroening \& Kendrick, 1987, 1989). In these two cases, the induction of histidine ammonia lyase, the first enzyme of the histidine catabolic pathway, is not repressed by glucose or $\mathrm{NH}_{4}^{+}$. The urocanic acid produced by histidase has been postulated as the inducer of the $S$. coelicolor hut system (Kendrick \& Wheelis, 1982), whereas in $S$. griseus, histidase activity is regulated post-translationally (Kroening \& Kendrick, 1987, 1989).

The knowledge gained in this study has laid the foundation for an investigation of the genetics of valine catabolism in $S$. coelicolor A3(2). Towards this end we have isolated $S$. coelicolor A3(2) Vut ${ }^{-}$mutants that are unable to utilize valine as the sole $\mathrm{C}$ and $\mathrm{N}$ source (unpublished results). VDH activity could not be induced above the basal level in one of them. Further study of these and $S$. coelicolor A3(2) $\mathrm{VDH}^{-}$mutants should lead to an understanding of the genetic regulation of VDH in this organism.

We are grateful to Stefano Donadio, Ali Shafiee and Juan Imperial for their helpful comments and interest in this work, to Dexter Northrop for advice and assistance with the analysis of the enzyme kinetic data, and to John Robinson for information about the $S$. cinnamonensis VDH prior to publication. The chemically-defined growth medium used with $S$. cinnamonensis was developed at Eli Lilly and Co. by Derek McGilvery. J.A.V. was a recipient of a Fulbright/Spanish Ministerio de Educación fellowship. This research was supported in part by a grant from the National Institutes of Health (GM25799).

\section{References}

asano, Y., Nakazawa, A., Endo, K., Hibino, Y., Ohmori, M., NumAo, N. \& KonDO, K. (1987). Phenylalanine dehydrogenase of Bacillus badius. European Journal of Biochemistry 168, 153-159.

BRADFORD, M. M. (1976). A rapid and sensitive method for the quantitation of microgram quantities of protein utilizing the principle of protein-dye binding. Analytical Biochemistry 72, 248254.

Brendelberger, G., Retey, J., Ashworth, D. M., Reynolds, K., WILLENBROCK, F. \& RoBINSON, J. A. (1988). Enzymatic conversion of isobutyryl- to butyrylcarba(dethia)coenzyme A. A coenzyme $\mathbf{B}_{12}$ dependent rearrangement. Angewandte Chemistry International Edition in English 27, 1089-1090.

Cleland, W. W. (1979). Substrate inhibition. Methods in Enzymology 63, 500-513.

Dotzlaf, J. E., Metzger, L. S. \& Foglesong, M. A. (1984). Incorporation of amino acid-derived carbon into tylactone by Streptomyces fradiae GS14. Antimicrobial Agents and Chemotherapy 25, 216-220.

DugGleBY, R. G. (1984). Regression analysis of nonlinear Arrhenius plots: an empirical model and a computer program. Computers in Biology and Medicine 14, 447-455.

FISHER, S. H. (1988). Nitrogen assimilation in Streptomyces. In Biology of Actinomycetes ' 88, pp. 47-51. Edited by Y. Okami, T. Beppu \& H. Ogawara. Tokyo: Japan Scientific Societies Press.

HoDGson, D. A. (1982). Glucose repression of carbon source uptake and metabolism in Streptomyces coelicolor A3(2) and its perturbation in mutants resistant to 2-deoxyglucose. Journal of General Microbiology 128, 2417-2430.

HoPwOOD, D. A. (1988). Towards an understanding of gene switching in Streptomyces, the basis of sporulation and antibiotic production. Proceedings of the Royal Society B325, 121-138.

Hopwood, D. A., Bibb, M. J., Chater, K. F., Kieser, T., Bruton, C. J., Kieser, H. M., Lydiate, D. J., SMITH, C. P., WARD, J. M. \& SCHREMPF, H. (1985). Genetic Manipulation of Streptomyces. A Laboratory Manual. Norwich: John Innes Foundation.

Hutchinson, C. R. (1988). Impact of genetic engineering on the commercial production of antibiotics by Streptomyces and related bacteria. Applied Biochemistry and Biotechnology 16, 169-190.

KENDRICK, K. E. \& WHEELIS, M. L. (1982). Histidine dissimilation in Streptomyces coelicolor. Journal of General Microbiology 128, 20292040.

Kroening, T. A. \& Kendrick, K. E. (1987). In vivo regulation of histidine ammonia-lyase activity from Streptomyces griseus. Journal of Bacteriology 169, 823-829.

KROENING, T. A. \& KENDRICK, K. E. (1989). Cascading regulation of histidase activity in Streptomyces griseus. Journal of Bacteriology 171, 1100-1105.

MADDURI, K., StUTTARD, C. \& Vining, L. C. (1989). Lysine catabolism in Streptomyces spp. is primarily through cadaverine: $\beta$-lactam producers also make $\alpha$-aminoadipate. Journal of Bacteriology 171, 299-302.

MAGASANIK, B. \& NeIDHARdT, F. C. (1987). Regulation of carbon and nitrogen utilization. In Escherichia coli and Salmonella typhimurium. Cellular and Molecular Biology, pp. 1318-1325. Edited by F. C. Neidhardt. Washington, DC: American Society for Microbiology.

Massey, L. K., SoKatch, J. R. \& ConRad, R. S. (1976). Branchedchain amino acid catabolism in bacteria. Bacteriology Review 40 , 42-54.

Matin, R. R., Marsialil, V. D., Sokatch, J. R. \& Unger, L. (1973). Common enzymes of branched-chain amino acid catabolism in Pseudomonas putida. Journal of Bacteriology 115, 198-204.

OMURA, S. \& TANAKA, Y. (1984). Biochemistry, regulation and genetics of macrolide production. In Macrolide Antibiotics, pp. 199-231. Edited by S. Omura. New York: Academic Press.

Omura, S., Tanaka, Y., Mamada, H. \& Masuma, R. (1983a). Ammonium ion suppresses the biosynthesis of tylosin aglycone by interference with valine catabolism in Streptomyces fradiae. Journal of Antibiotics 36, 1792-1794. 
Omura, S., Tsuzuki, K., Tanaka, Y., Sakakibara, H., Aizawa, M. \& LUKACS, G. $(1983 \mathrm{~b})$. Valine as a precursor of the $n$-butyrate unit in the biosynthesis of macrolide aglycones. Journal of Antibiotics 36, 614-616.

Omura, S., Tanaka, Y., Mamada, H. \& Masuma, R. (1984a). Effect of ammonium ion, inorganic phosphate, and amino acids on the biosynthesis of protylonolide, a precursor of tylosin aglycone. Journal of Antibiotics 37, 494-502.

Omura, S., Tanaka, Y., Mamada, H. \& Masuma, R. (1984b). Ammonium ions suppress the amino acid metabolism involved in the biosynthesis of protylonolide in a mutant of Streptomyces fradiae. Journal of Antibiotics 37, 1362-1369.

Porumb, H., Vancea, D., Muresan, L., Presecan, E., Lascu, I. Petrescu, I., Porumb, T., PoP, R. \& Barzu, O. (1987). Structural and catalytic properties of $\mathrm{L}$-alanine dehydrogenase from Bacillus cereus. Journal of Biological Chemistry 262, 4610-4615.

Pospisil, S., Sedmera, P., Havranek, M., KRUMPhazl, V. \& Vanek, Z. (1983). Biosynthesis of monensins A and B. Journal of Antibiotics 36, 617-619.

Priestly, N. D. \& Robinson, J. A. (1989). Purification and catalytic properties of L-valine dehydrogenase from Streptomyces cinnamonensis. Biochemistry Journal 261, 853-861.

Sood, G. R., Ashworth, D. M., AJAZ, A. A. \& Robinson, J. A. (1988). Biosynthesis of the polyether antibiotic monensin-A. Results from the incorporation of labelled acetate and propionate as a probe of the carbon chain assembly process. Journal of the Chemical Society Perkin Transactions I 1988, 3183-3194.

ReYnolds, K. A., O'Hagen, D., Gani, D. \& Robinson, J. A. (1988). Butyrate metabolism in streptomycetes. Characterization of an intramolecular vicinal interchange rearrangement linking isobutyrate and butyrate in Streptomyces cinnamonensis. Journal of the Chemical Society Perkin Transactions I 1988, 3195-3208.
SCHutTe, H., Hummerl, W., Tsai, H. \& Kula, M.-R. (1985). LLeucine dehydrogenase from Bacillus cereus. Applied Microbiology and Biotechnology 22, 306-317.

Sherman, M. M., Yue, S. \& Hutchinson, C. R. (1986). Biosynthesis of lasalocid A. Metabolic interrelationships of carboxylic acid precursors and polyether antibiotics. Journal of Antibiotics 39, 1135-1143.

Smith, E. L., Austin, B. M., BLumenthal, K. M. \& NYC, J. F. (1975) Glutamate dehydrogenases. In The Enzymes, vol. XI, pp. 294-368. Edited by P. D. Boyer. New York: Academic Press.

Vancura, A., Rezanka, T., Marsalek, J., Vancurova, I., Kristan, V. \& Basarova, G. (1987). Effect of ammonium ions on the composition of fatty acids in Streptomyces fradiae, producer of tylosin. FEMS Microbiology Letters 48, 357-360.

Vancura, A., Vancurova, I., Volc, J., Fussey, S. P. M., Flieger, M., Neuzil, J., MarsaleK, J. \& Behal, V. (1988). Valine dehydrogenase from Streptomyces fradiae: purification and properties. Journal of General Microbiology 134, 3213-3219.

Vancura, A., Vancurova, I., Volc, J., Jones, S. K. T., Flieger, M., Basarova, G. \& BeHAL, V. (1989). Alanine dehydrogenase from Streptomyces fradiae. European Journal of Biochemistry 179, 221-227.

Vancurova, I., Vancura, A., Volc, J., Neuzil, J., Flieger, M., BASAROVA, G. \& BEHAL, V. (1988a). Isolation and characterization of valine dehydrogenase from Streptomyces aureofaciens. Journal of Bacteriology 170, 5192-5196.

Vancurova, I., Vancura, A., Volc, J., Neuzil, J., Flieger, M., Basarova, G. \& Behal, V. (1988b). Purification and partial characterization of alanine dehydrogenase from Streptomyces aureofaciens. Archives of Microbiology 150, 438-440.

Vara, J. A. \& Hutchinson, C. R. (1988). Purification of thymidinediphospho-D-glucose 4,6-dehydratase from an erythromycin-producing strain of Saccharopolyspora erythraea by high resolution liquid chromatography. Journal of Biological Chemistry 263, 14992-14995. 